\title{
Florin Dumitrescu, Tradiții la supraofertă. Între socoteala din agenție și cea de la raft, Cartier Antropologic, Chișinău, 2015, 191 p.
}

\author{
Ioana Repciuc* \\ Institutul de Filologie Română „A. Philippide”, Str. Th. Codrescu 2, 700481 Iași, România
}

Mesajul publicitar este astăzi studiat din perspectiva mai multor discipline, cum ar fi antropologia, sociologia, lingvistica, critica literară, istoria culturală. Marcat de principiul utilitarist, procesul de concepere a acestui tip de text impune cunoașterea în profunzime a realităţilor sociale și utilizarea creativă a unei game diverse de resurse lingvistice. Din punctul de vedere al lingvistului, publicitatea este şi un context în care se poate studia valoarea perlocutorie a limbajului. Specialiștii în retorica argumentării publicitare au fost interesați de modul în care comunicarea acționează asupra realităţii sau de parametrii relației dintre creatorul mesajului şi receptor. Antropologul se va orienta spre explicarea strategiei prin care autorul de mesaj publicitar manipulează anumite convenții etnoculturale sau dispoziții psihosociale ale eventualilor cumpărători, încercînd să convingă prin apelul mediat la aceste refracții interioare ale receptorului. În Statele Unite, acolo unde a fost consacrată înțelegerea publicităţii ca un indicator al curentelor de opinie și de gust specifice societății căreia îi este adresată s-au evidențiat de acum cîteva decenii principiile de organizare a diverselor strategii semiotice funcționînd la baza acesteia (Marchand, 1985; Leach, 1993; Fox, 1997).

În spaţiul româneasc, avînd în vedere instalarea marketingului de tip occidental abia după căderea comunismului, un „specific național” al domeniului s-a lăsat mult așteptat, astfel încît și aspiraţiile exegetice de a-l puncta şi explica au întîrziat să apară. Volumul semnat de Florin Dumitrescu se circumscrie acestei noi întreprinderi și poate fi citit şi ca o scurtă sinteză asupra celor cîtorva momentecheie din publicitatea românească post-decembristă a produselor alimentare de larg consum. Dintre acestea, autorul licențiat în Litere la Universitatea din București se oprește asupra publicității anilor 2000, cînd se impun pe piața românească a produselor folosirea constructelor culturale cu tema tradițiilor, şi anume identificare alimentelor cu sloganul „ca la mama acasă”, „ca la țară”, „ca odinioară” (p. 8). Este vorba despre un trend devenit stabil în ultimele două decenii care a apărut odată cu lansarea cunoscutului Untdelemn de la Bunica.

Cartea este la origine lucrarea de doctorat în socio-antropologie a autorului, susținută în anul 2014 sub coordonarea lui Vintilă Mihăilescu. Pertinența acestei cercetări în mediul academic autohton este asigurată mai ales de penuria unor studii de gen, care să radiografeze cultura comercială românească din perspectiva specificului național și a stereotipurilor culturale. O excepție de la această regulă ar fi cercetările asupra brandului de țară, care s-au orientat de asemenea spre scanarea opiniei publice în ceea ce privește elemente culturale românești reprezentative și modele de business și de consum care le-au utilizat (Bogdan, 2011).

Cercetătorul beneficiază de situația de a fi activat el însuși, din 1995 în 2000, după studii de masterat în retorică și argumentație, în domeniul pe care1 studiază aici din poziția antropologului. Îmbină astfel cunoașterea din interior cu privirea din afară, întorcîndu-se la foștii colegi din departamentele de creație și strategie ale celor mai importante agenții de publicitate autohtone. Într-o pertinentă abordare holistică, Florin Dumitrescu alătură la interviurile cu membrii breslei pe cele realizate cu un eșantion reprezentativ de cumpărători, la care adaugă observația participativă ca sondare a comportamentului consumatorilor în supermarket și reacția lor directă la mesajul publicitar.

Tematica tradițională la care se referă aici autorul este caracterizată prin trăsături ca: nostalgia originilor, garantarea calității prin evocarea unui spațiu/timp legendar, afirmarea identității locale/naționale, preocuparea pentru puritatea sursei și

\footnotetext{
*Adresă de corespondență: repciuc_i_o@yahoo.com.
} 
alimentația sănătoasă (p. 9). Conştient de existența unui jargon mai puțin accesibil cititorilor din afara domeniului pe care-l ilustrează, cercetătorul fixează într-o primă secțiune a volumului terminologia la care apelează (p. 14-16). În primele trei capitole, analizează folosirea argumentului tradiționalist în comunicarea comercială într-o viziune diacronică și clasifică funcționarea acestuia în diferite compartimente ale fluxului de producție (p. 16-29), schițează aspirațiile producătorilor și direcțiile principale ale pieței de profil (p. 30-47) și apoi examinează raportul dinamic și negocierea dintre așteptările concrete ale consumatorilor și veleitățile creative ale publicitarilor (p. 48-87). În a doua parte a volumului, sunt discutate pe rînd cîteva campanii de brand exponențiale pentru tematica de față: Untdelemn de la Bunica (p. 88-108), Napolact și Covalact (p. 109147), Matache Măcelaru' (p. 148-153), Scandia Sibiu și Ardealul (p. 164-170).

Retorica marketingului tradițiilor gastronomice oferă o nouă perspectivă asupra statutului tradiției în modernitate și ilustrează o ipostază a mult-discutatei "glocalizări” ${ }^{1}$ din marketingul contemporan. În coerență cu ideile cunoscutului teoretician al ideii de tradiție analizate sincronic și diacronic, Edward Shils, manifestările tradiționale sunt normative, în sensul în care acestea mediază comportamentul oamenilor dincolo de acordul acestora la corectitudinea factuală a conţinutului (Shils, 1981, p. 24). Pe aceeaşi linie, antropologul cognitiv Pascal Boyer a demonstrat că ceea ce se transmite din cunoașterea tradițională sunt mai puțin opiniile și concepțiile despre lume specifice trecutului, ci indivizii așa-numiți „conservatori” se rezumă la a repeta oarecum inconștient trăsăturile de suprafață ale fenomenelor culturale de care se atașează (Boyer, 1991, p. 13-14). Astfel, rezultatele cercetărilor lui Florin Dumitrescu confirmă interpretarea teoreticienilor tradiției, întrucit ajunge la concluzia că nu conţinutul retoricii îi convinge pe majoritatea consumatorilor, ci atracția pentru discursul tradiției. Forța perlocutorie a publicităţii tradiționaliste nu stă în mesajul despre produsul de vînzare, ci în povestea spusă în discursul de marketing. Consumerismul actual al românilor este motivat în mod neașteptat de această întoarcere în timp.

Într-o abordare diacronică, autorul explică trecerea de la începuturile marketingului românesc de după comunism, reprezentat de accentuarea interfeței occidentale a produselor-situație logic determinată de nevoia de imitare a unor modele deja consacrate în Occident din partea publicitarilor şi a aspirației consumatorilor de a se alinia la valorile euro-atlantice-la o regăsire a farmecului tradiției autohtone (p. 38). Această revenire la tradiţie se petrece sub imboldul unei nostalgii pentru trecut, pentru gusturile şi produsele de odinioară, pentru tărîmul fantasmatic și bucolic al satului. Dumitrescu vede aici o turnură radicală care duce la construirea unor branduri paseiste de către marile companii de publicitate din România (p. 42). Acest fenomen se produce împotriva preferinței declarate a creatorilor de publicitate, formați deja în tradiția marketingului occidental şi reacționînd negativ la temele paseiste clasice, cum ar fi: fatalismul mioritic, eternul complex al „țărănismului”, ceauşismul, pășunismul, vechiul naţional-comunism.

Aproape împotriva propriei voințe, experții în branding sunt obligați să răspundă pozitiv la cerințele clienților și să producă mesajele pășuniste, devenind „manipulatori manipulați” (p. 86). Dumitrescu descrie convingător această dificilă negociere între plăcerile arcadice ale cumpărătorilor și pragmatismul occidental al creatorilor de brand. Împăcarea celor două s-a produs prin crearea unui tradiționalism sui generis, avînd drept conținut dominant clișeele culturale indigene, dar punerea în scenă de inspirație occidentală. Dezgustați de vechiul naționalism, directorii de imagine creează unul nou, pe calapodul mai atrăgător al culturii vestice (p. 57). Din această împăcare forțată apare filtrul ironic și detașarea cu care este reprezentată ruralitatea românească tipică, o abordare bazată consistent pe umorul neaoș și trăsăturile îngroșate ale portretelor de țărani și tîrgoveți (p. 70).

Din discuțiile cu gospodinele, autorul descoperă

\footnotetext{
${ }^{1}$ Termen introdus în anii '90 în vocabularul științelor socio-economice pentru a desemna îmbinarea între efectele globalizării și cele ale localizării în funcționarea sistemelor sociale, politice și economice contemporane. În sociologie, cuvântul a fost introdus şi teoretizat de sociologul american Roland Robertson, care l-a preluat din jargonul mediului de afaceri japonez (Robertson, 1995 , p. 29 ș. urm.). Va fi apoi prima dată aplicat de Wellman \& Hampton (1999, p. 651): „We call this process glocalization: the combination of global connectivity and local activity”. Ca strategie de marketing, domeniu în care a devenit foarte populară în ultimele decenii, glocalizarea presupune adaptarea brandurilor globale la aşteptările și gusturile consumatorilor locali (Dumitrescu \& Vinerean, 2010).
} 
preferința acestora pentru referința antropică, figurile tutelare ale brandului promovate prin spoturile publicitare și pe etichetele artistice ale produselor, deși înțeleg artificiul și convenția din spatele respectivei strategii publicitare: „Schematic spus, le place să creadă că e de la Coana Chiva, dar preferă să știe că e din fabrică” (p. 78). În continuarea argumentării, biografiile produselor tradiționaliste ilustrează și mai clar articularea acestei negocieri și întreaga desfășurare a creării unui brand. Din capitolul dedicat succesului de piață al Untdelemnului de la Bunica este concludent în special interviul cu „părintele” Bunicii, George Nicolae, cel care a avut „geniala inspirație de a-și da seama că un trecut va «vinde» în viitor” (p. 99). Pentru a reuși să se relaționeze cu așteptările cumpărătorilor autohtoni, onomaturgul brandului de „untdelemn” a apelat nu la studii de piață, cum era de așteptat, ci la istoria mentalităţilor și la antropologie culturală, la cărțile despre mituri și legende românești ale lui Mircea Eliade.

Poveștile figurilor care patronează brandurile tradiționaliste, analizate din perspectivă retorică, estetică şi antropologică formează cea mai consistentă parte a capitolelor următoare. De pildă, brandcharacterul Coana Chiva, care a asigurat succesul iaurtului Covalact întruchipează o mutaţie de la figura suavă a Bunicii la tonul avintat al precupeței tipice (p. 129). Pe aceeași direcție se fixează Matache Măcelaru', prezentat ca un mezelar legendar din Bucureștiul de acum două secole, care evocă „negustorul paradigmatic, dintr-un timp idealizat” (p. 151). Pateurile Scandia Sibiu și Ardealul mizează în schimb pe redarea comensualității idilice, pe întîlnirea și sărbătorirea în colectivitate (p. 159).

Apetența cumpărătorilor de a fi seduși de retorica publicitară pe teme tradiționaliste se opune cu pregnanță mediului hiperconsumist, industrializat și eficientizat al supermarketului în care se întîlnesc cu produsele. Deși sunt cumpărători fideli ai produsele în serie, consumatorii gustă povestea unicității de pe etichetă. Florin Dumitrescu citește aici nostalgia pentru atmosfera tîrgurilor, cu zgomotele și gesturile specifice. Aceasta este şi interpretarea sintetică pe care autorul o oferă fenomenului de „supermarketizare a tradițiilor" în capitolul de concluzii intitulat sugestiv „De la tîrg la supermarket și înapoi” (p. 171181). Reliefarea punerii în scenă a tîrgului de altădată în supermarketul de astăzi e în consens cu subiectul primului volum în antropologie al cercetătorului (Dumitrescu, 2013). Încercînd să explice protestelemaraton din Piața Universităţii desfășurate în anii '90, Dumitrescu le-a privit ca pe o manifestare în care s-au regăsit deopotrivă sacrul și profanul, comercialul și carnavalescul din vechile piețe agroalimentare.

Deși nu se poate nega importanța şi caracterul inovator al cercetării de față, ar fi fost adecvată amplasarea argumentației autorului în contextul mai larg al considerațiilor istoricilor americani clasici ai publicității. Aceștia au observat tendința reclamelor celei mai înfloritoare creșteri a pieței de consum americane din perioada postbelică de a se înscrie în imaginarul socio-cultural al belșugului domestic și al idealizării vieții de familie, la care se adăuga invocarea animismului specific în fapt societăților tradiționale (Samuel, 2001, p. 3). Dintr-o perspectivă antropologică, publicitatea devine prin urmare un domeniu al manipulării prin magie (Williams, 1980) sau unul, așa cum îl descria Roland Barthes într-un text celebru despre semiotica publicitară, care pune în discuție cele mai profunde zone ale condiției umane (Barthes, 1963, p. 95), în ciuda forței irezistibile a mitului progresului în comunicarea comercială.

\section{Bibliografie}

Barthes, R. (1963). Le message publicitaire, rêve et poésie, în „Communication \& Languages”, nr. 7, p. 91-96, CrossRef.

Bogdan, A. (2011). Branding pe frontul de Est: despre reputație, impotriva curentului, cuvînt înainte de Wally Olins, Brandient, București.

Boyer, P. (1991). Tradition as truth and communication. A cognitive description of traditional discourse, Cambrige University Press.

Dumitrescu, F. (2013). Bîlciul Universității. Descoperind spiritul tîrgoveț în Bucureștiul postsocialist (e-book), Editura Humanitas, București.

Dumitrescu, L. \& Vinerean, S. (2010). The glocal strategy of global brands, în „Studies in Business and Economics”, vol. 5, nr. 3, p. 147155.

Fox, S. (1997). The Mirror Makers: A History of American Advertising and Its Creators, University of Illinois Press, Urbana.

Leach, W. (1993). Land of Desire: Merchants, Money, and the Rise of a New American Culture, Vintage Books, New York.

Marchand, R. (1985). Advertising the American Dream: Making Way for Modernity, 1920-1940, University of California Press, Berkeley. 
Robertson, R. (1995). Glocalization: Time-Space and Homogeneity-Heterogeneity, în Featherstone, M., Lash, S. \& Robertson, R. (eds), Global Modernities, Sage Publications, London / Thousands Oaks, New Delhi, p. 25-44.

Samuel, L. R. (2001). Brought to you by. Postwar Advertising and the American Dream, University of Texas Press, Austin.

Shils, E. (1981). Tradition, University of Chicago Press.

Wellman, B. \& Hampton, K. (1999). Living Networked On and Offline, în „Contemporary Sociology”, vol. 28, nr. 6, p. 648-654, CrossRef.

Williams, R. (1980). Advertising: The magic system, în Problems in Materialism and Culture, Verso, London, p. $170-195$. 